\section{A Protein Inhibiting Pancreatic Lipase Activity in Soybean Seeds}

\section{Tomohiko Mori, Kiyoshi SatouchI and Setsuro Matsushita}

\author{
Research Institute for Food Science, \\ Kyoto University, Kyoto
}

Received February 20, 1973

It has been reported that a heat-stable protein in the castor bean increases its lipase activity. ${ }^{1)}$ Recently a porcine pancreatic colipase, an effector necessary for pancreatic lipase, was reported. ${ }^{2)}$ On the other hand, a protein inhibitor for the lipase activity of rat pancreas extracts has been found in rat liver homogenate. ${ }^{3)}$ These protein factors have been considered to play physiologically important role in the lipolysis. We have observed that soybean extract contains an inhibitor factor to the lipase activity of porcine pancreas powder. An attempt to characterize the nature of the inhibitor factor is described in this paper.

The activity of lipase was assayed by determining the formation of free fatty acid by a modification of the method described by Duncombe." The substrate used was a soybean oil emulsion prepared by vigorous stirring with $10 \mathrm{ml}$ of $5 \%$ gum arabic and $1 \mathrm{ml}$ of soybean oil. The assays were performed in $10 \mathrm{ml}$ centrifuge tube in a total volume of $0.5 \mathrm{ml}$ containing $50 \mu$ moles of Tris- $\mathrm{HCl}$, pH $7.4,0.5 \mu$ mole of calcium acetate, $50 \mu \mathrm{l}$ of soybean oil emulsion and $50 \mu \mathrm{g}$ protein of pancreatic lipase (Sigma Type II crude) for $30 \mathrm{~min}$ at $37^{\circ} \mathrm{C}$. The reaction was terminated by addition of $4 \mathrm{ml}$ of chloroform and the mixture was shaken for $90 \mathrm{sec}$. After centrifugation, the upper layer was removed by suction. To the chloroform phase was added $3 \mathrm{ml}$ of a mixture containing $9 \mathrm{vol}$. of $1 \mathrm{M}$ triethanolamine, $1 \mathrm{vol}$. of $1 \mathrm{~N}$ acetic acid and 10 vol. of $6.45 \% \mathrm{Cu}\left(\mathrm{NO}_{3}\right)_{2} \cdot 3 \mathrm{H}_{2} \mathrm{O}$ and tube was shaken for $5 \mathrm{~min}$. It was then centrifuged, and the upper aqueous phase was removed by suction. The residual chloroform layer was filtered, ${ }^{5}$, and $0.5 \mathrm{ml}$ of $0.1 \%$ sodium diethyldithiocarbamate in $n$-butanol was added. After mixing, the color was measured at $440 \mathrm{~m} \mu$ against a reagent blank.

Dry soybean cotyledon was ground and homogenized in a mortar with $0.1 \mathrm{M}$ Tris- $\mathrm{HCl}$, $\mathrm{pH} 7.4$ containing $1 \mathrm{~mm}$ calcium acetate (one grain $/ 2 \mathrm{ml}$ ). The homogenate was centrifuged at $10,000 \times g$ for $30 \mathrm{~min}$ and the supernatant was fractionated with ammonium sulfate.

Table I. Effect of Various Treatment on the ACTIVITY OF INHIBITOR FACTOR

The inhibitor factor was heated for $10 \mathrm{~min}$ at $100^{\circ} \mathrm{C} .40 \mathrm{mg}$ of the inhibitor factor were incubated with $4 \mathrm{mg}$ of pronase in a $1 \mathrm{ml}$ of $0.1 \mathrm{M} \mathrm{Tris}-\mathrm{HCl}$, pH 7.4 containing $1 \mathrm{~mm}$ calcium acetate for $3 \mathrm{hr}$ at $37^{\circ} \mathrm{C}$. The lipase activity was determined as described in the text, using linoleic acid as a standard.

\begin{tabular}{lcc}
\hline \multicolumn{1}{c}{ Additions } & \multicolumn{1}{c}{$\begin{array}{c}\text { Lipase activity } \\
\text { (m } \mu \text { moles of linoleic acid) }\end{array}$} \\
\hline None & & 695 \\
Untreated factor & $100 \mu \mathrm{g}$ & 416 \\
& $200 \mu \mathrm{g}$ & 206 \\
Heated factor & $200 \mu \mathrm{g}$ & 689 \\
$\begin{array}{l}\text { Pronase treated } \\
\text { factor }\end{array}$ & $200 \mu \mathrm{g}$ & 689 \\
\hline
\end{tabular}

The ammonium sulfate fraction precipitating between 0.25 and 0.5 saturation was dialyzed against $0.1 \mathrm{~m}$ Tris- $\mathrm{HCl}, \mathrm{pH} 7.4$. The dialyzed preparation markedly inhibited the lipase activity (Table I). The inhibitory effect was abolished by pronase treatment or by heat treatment. The inhibitory factor caused no significant disappearance of added linoleic acid in the incubation system or no effect on the step of extracting free fatty acid from incubation mixture and color development. Amylase and ribonuclease were not inhibited by this factor. It seems that the inhibitor factor is specific for lipase.

Further purification of the inhibitor protein and characterization of the inhibiton are now in progress. 


\section{REFERENCES}

1) R. L. Ory, H. W. Kircher and A. M. Altschul, Biochim. Biophys. Acta, 147, 200 (1967).

2) M. F. Maylie, M. Charles, C. Gache and P. Desnuelle, ibid., 229, 286 (1971).
3) R. Machovich, J. Csillag and A. Naray, FEBS LETTERS, 9, 119 (1970).

4) W. G. Duncombe, Biochem. J., 88, 7 (1963).

5) K. Itaya and M. Ui, J. Lipid Research, 6, 16 (1965). 